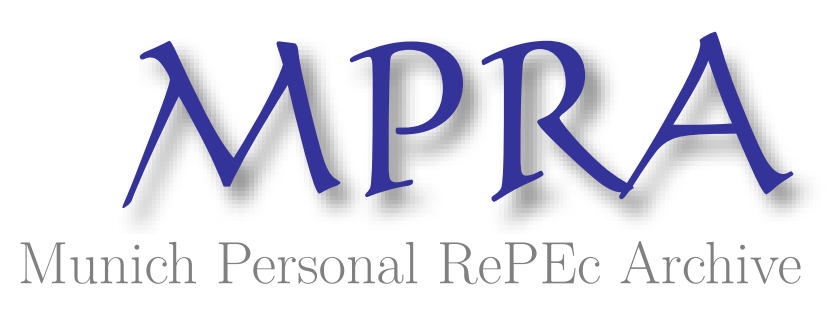

\title{
Consumption in developed and emerging economies.
}

Kadish, Peter

August 2010

Online at https://mpra.ub.uni-muenchen.de/24361/

MPRA Paper No. 24361, posted 12 Aug 2010 10:20 UTC 
Consumption in developed and emerging economies.

Peter Kadish, August 2010

\begin{abstract}
In what follows various econometric technique is applied to determine the source of consumption growth with historical retrospective to equity and real estate markets as well comparative analysis of US consumer and Chinese consumer is presented.
\end{abstract}

JEL Classification : E21 


\section{Developed market perspective}

Equity boom in the US that started in mid 1990s has been driving consumer wealth and consumer credit $\left(\mathrm{CC}^{1}\right)$ with it up to the early 2000 when deregulation in the financial sector coupled with development of sophisticated financial products allowed to securitize illiquid assets, increasing wealth of consumer via raise in the price of previously illiquid assets like real estate (Chart 1 ). Laibson, Mollerstrom (2010) have argued that asset price movements, including the equity markets and residential real estate markets are capable of explaining international financial flows (i.e. private debt buildup). During the period of inflated asset values, US consumers spent their new wealth, with marginal propensity to consume of about $4 \%$. The asset bubble framework quantitatively explains the large current account deficit of the US.

Chart1. S\&P Index (orange line), Household Wealth (net worth, white line) and House Prices (S\&P/Case-Shiller Home Price Index, yellow line). 1990-2010

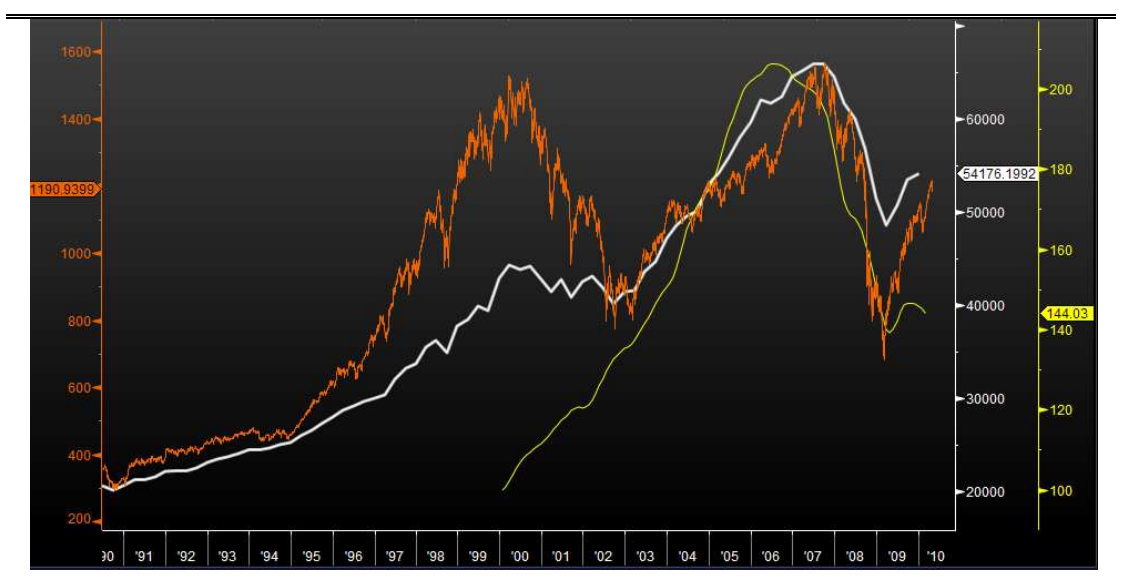

Data source: Bloomberg

1 The total outstanding consumer credit amount. This index is taken from the G.19 report disseminated by the Federal Reserve. Covers most short and intermediate term credit extended to individuals, excluding loans secured by real estate. 
Chart 2. Consumer Debt/Disposable Income ratio, 1970-2009.

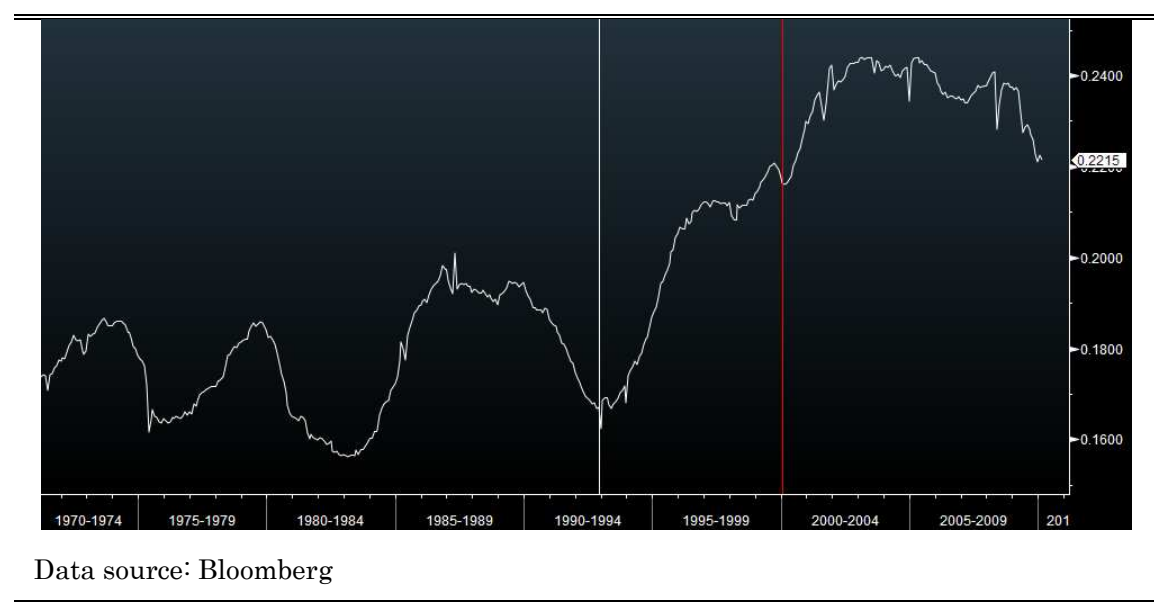

Chart 2 shows that consumer credit started to decouple from disposable income in mid 1990s when equity market rate of growth has increased. To account for possible structural change in the rate of growth in equity market the dummy regression model is applied. Results in Table 1 confirm that there has been indeed a significant change in the pre and post 1995 equity price growth rates.

\section{Table1}

The following model is proposed: $\operatorname{lnS} \& \mathrm{P}_{t}=\alpha_{1}+\alpha_{2} D_{t}+B_{1} t+B_{2}\left(D_{t}{ }^{*} t_{t}\right)+\mu_{t}$; Regressand is the logarithm of $Y$ and the regressor is "time," which will take values of 1, 2,3, etc. Dummy Takes the value of 0 for older subperiod and 1 for latter subperiod. Subperiods 19901995 and 1995-2000, monthly data. Data adjusted for autocorrelation via Newey-West HAC Standard Errors \& Covariance (lag truncation=5). Data source: Bloomberg.

Dependent Variable: LOGSPX

Method: Least Squares

Sample: 1120

Included observations: 120

\begin{tabular}{lrlrr}
\hline \hline \multicolumn{1}{c}{ Variable } & Coefficient & \multicolumn{1}{c}{ Std. Error } & t-Statistic & Prob. \\
\hline \hline \multicolumn{1}{c}{ C } & 5.801010 & 0.012463 & 465.4716 & 0.0000 \\
TIME & 0.006728 & 0.000355 & 18.93505 & $\mathbf{0 . 0 0 0 0}$ \\
DUM & -0.740617 & 0.035032 & -21.14095 & $\mathbf{0 . 0 0 0 0}$ \\
\multicolumn{1}{c}{ DUM*TIME } & 0.011980 & 0.000503 & 23.84056 & $\mathbf{0 . 0 0 0 0}$ \\
\hline \hline R-squared & 0.989077 & Mean dependent var & 6.379853 \\
Adjusted R-squared & 0.988795 & S.D. dependent var & 0.450291 \\
S.E. of regression & 0.047666 & Akaike info criterion & -3.216452 \\
Sum squared resid & 0.263552 & Schwarz criterion & -3.123535 \\
Log likelihood & 196.9871 & Hannan-Quinn criter. & -3.178718 \\
F-statistic & 3501.338 & Durbin-Watson stat & 0.635720 \\
Prob(F-statistic) & 0.000000 & & \\
\hline \hline
\end{tabular}


Results show that both diffferencial intercept and slope coefficients are statistically significant, strongly suggesting that the growth rate of S\&P Index for two sample periods differ. Since equity income is part of consumer wealth (household worth, as in Federal Reserve form B.100 Flow of Funds release) it comes at no surprise that surge in wealth is caused by S\&P index trend change. We test for the structural shift in consumer credit with benchmark year $1995^{2}$. Results presented in Table 2 in reconfirm for structural change in 1995.

Table 2

\begin{tabular}{|c|c|c|c|c|}
\hline \multicolumn{5}{|c|}{$\begin{array}{l}\text { The following model is proposed: } C_{t}=\alpha_{1}+\alpha_{2} D_{t}+B_{1} t+B_{2}\left(D_{t}{ }^{*} t_{t}\right)+\mu_{t} \text {; Regressand is the } Y \\
\text { and the regressor is "time," which will take values of } 1,2,3 \text {, etc. Dummy Takes the } \\
\text { value of } 0 \text { for older subperiod and } 1 \text { for latter subperiod. Subperiods } 1990-1995 \text { and } \\
\text { 1995-2000, monthly data. Data adjusted for autocorrelation via Newey-West HAC } \\
\text { Standard Errors \& Covariance (lag truncation=5). }\end{array}$} \\
\hline \multicolumn{5}{|c|}{$\begin{array}{l}\text { Dependent Variable: COONSUMER CREDIT (CC) } \\
\text { Method: Least Squares } \\
\text { Sample: } 1433 \\
\text { Included observations: } 433 \\
\text { Newey-West HAC Standard Errors \& Covariance (lag truncation=5) }\end{array}$} \\
\hline \multicolumn{5}{|c|}{$\begin{array}{lllll}\text { Variable } & \text { Coefficient } & \text { Std. Error } & \mathrm{t} \text {-Statistic } & \text { Prob. }\end{array}$} \\
\hline $\mathrm{C}$ & 88.50460 & 12.53731 & 7.059300 & 0.0000 \\
\hline DUM & -1663.761 & 36.39433 & -45.71485 & 0.0000 \\
\hline TIME & 3.159235 & 0.078704 & 40.14095 & 0.0000 \\
\hline DUM*TIME & 6.595812 & 0.122910 & 53.66359 & 0.0000 \\
\hline \multirow{7}{*}{$\begin{array}{l}\text { R-squared } \\
\text { Adjusted R-squared } \\
\text { S.E. of regression } \\
\text { Sum squared resid } \\
\text { Log likelihood } \\
\text { F-statistic } \\
\text { Prob(F-statistic) }\end{array}$} & \multirow{7}{*}{$\begin{array}{r}0.997360 \\
0.997341 \\
37.97496 \\
618659.9 \\
-2187.180 \\
54018.62 \\
0.000000\end{array}$} & \multicolumn{2}{|c|}{ Mean dependent var } & 1023.139 \\
\hline & & \multicolumn{2}{|c|}{ S.D. dependent var } & 736.4816 \\
\hline & & \multicolumn{2}{|c|}{ Akaike info criterion } & 10.12093 \\
\hline & & \multicolumn{2}{|c|}{ Schwarz criterion } & 10.15853 \\
\hline & & \multicolumn{2}{|c|}{ Hannan-Quinn criter. } & 10.13577 \\
\hline & & \multicolumn{2}{|c|}{ Durbin-Watson stat } & 0.021154 \\
\hline & & & \\
\hline
\end{tabular}

The $2^{\text {nd }}$ benchmark candidate for structural change is expected to be year $2000^{3}$, when GlassSteagall act has been repealed. Initial assumption has been related to consumption financed with debt or bank debt (which is the asset side of the banking sector). In order to account for possible

\footnotetext{
${ }^{2}$ It is possible that change in legislation might have caused decoupling of credit aggregates. In particular, the 1995 New Community Reinvestment Act, which strengthened the role of Fannie Mae and Freddie Mac in mortgage markets and facilitated mortgage securitization.

${ }^{3}$ There have been legislation change in 1999 - Gramm-Leach-Bliley Act, which removed the prohibition that prevented bank holding companies from owning other financial companies and 2000 Commodity Futures Modernization Act, which stipulated that financial derivatives such as CDOs would not be regulated as futures contracts, securities.
} 
policy shift after the Glass-Steagall act has been repealed at the end of $1999^{4}$ the analogue of the Chow test ${ }^{5}$ via dummy variables is employed. Results are presented in Table 3.

Table 3

\begin{tabular}{|c|c|c|c|c|}
\hline \multicolumn{5}{|c|}{$\begin{array}{l}\text { The following model is proposed: } \mathrm{BA}_{\mathrm{t}}=\mathrm{\alpha}_{1}+\mathrm{\alpha}_{2} \mathrm{D}_{\mathrm{t}}+\mathrm{B}_{1} \mathrm{GDP}+\mathrm{B}_{2}\left(\mathrm{D}_{\mathrm{t}}^{*} \mathrm{GDP} \mathrm{P}_{\mathrm{t}}\right)+\mu_{\mathrm{t}} \text { Regressand is } \\
\text { the } Y \text { and the regressor is "time," which will take values of } 1,2,3 \text {, etc. Dummy Takes } \\
\text { the value of } 0 \text { for older subperiod and } 1 \text { for latter subperiod. Subperiods } 1973-2000 \text { and } \\
2000-2008 \text {, quarterly data. Data adjusted for autocorrelation via Newey-West HAC } \\
\text { Standard Errors \& Covariance (lag truncation=5).Data source: Federal Reserve's } \\
\text { weekly H.8 report. }\end{array}$} \\
\hline \multicolumn{5}{|c|}{$\begin{array}{l}\text { Dependent Variable: Bank Assets (BA) } \\
\text { Method: Least Squares } \\
\text { Sample: } 1409 \\
\text { Included observations: } 409 \\
\text { Newey-West HAC Standard Errors \& Covariance (lag truncation=5) }\end{array}$} \\
\hline Variable & Coefficient & Std. Error & $\mathrm{t}$-Statistic & Prob. \\
\hline $\mathrm{C}$ & -70.17130 & 19.85841 & -3.533580 & 0.0005 \\
\hline GDP & 0.572823 & 0.005232 & 109.4861 & 0.0000 \\
\hline $\mathrm{GPD}{ }^{*} \mathrm{D}$ & 0.459075 & 0.023322 & 19.68449 & 0.0000 \\
\hline DUM & -4208.013 & 250.7430 & -16.78218 & 0.0000 \\
\hline R-squared & 0.998569 & \multicolumn{2}{|c|}{ Mean dependent var } & 3862.697 \\
\hline Adjusted R-squared & 0.998559 & \multicolumn{2}{|c|}{ S.D. dependent var } & 2545.807 \\
\hline S.E. of regression & 96.65542 & \multicolumn{2}{|c|}{ Akaike info criterion } & 11.98991 \\
\hline Sum squared resid & 3783619 . & \multicolumn{2}{|c|}{ Schwarz criterion } & 12.02917 \\
\hline Log likelihood & -2447.937 & \multicolumn{2}{|c|}{ Hannan-Quinn criter. } & 12.00544 \\
\hline F-statistic & 94214.03 & \multicolumn{2}{|c|}{ Durbin-Watson stat } & 0.363090 \\
\hline Prob(F-statistic) & 0.000000 & & & \\
\hline
\end{tabular}

As these regression results show, both the differential intercept and slope coefficients are statistically significant, strongly suggesting that the BANK ASSETS-GDP regressions for the two time periods are different. The same applies to BANK-ASSET-DISPOSABLE INCOME or BANK ASSETS-CONSUMER CREDIT relationships (regression results not presented here). We, therefore, conclude that banking sector has decoupled from the economy, whether measured relative to disposable income, GDP or consumption. This decoupling, however did not bring any surge in disposable income as presented in Table 4.

\footnotetext{
${ }^{4}$ The repeal enabled commercial lenders such as Citigroup, which was in 1999 the largest U.S. bank by assets, to underwrite and trade instruments such as mortgage-backed securities and collateralized debt obligations and establish so-called structured investment vehicles, or SIVs, that bought those securities. It was originally introduced in order to separate bank types according to their business (commercial and investment banking) in 1933 to exclude the possibility of commercial banks being too exposed to risky assets.

5 Gregory C. Chow, "Tests of Equality Between Sets of Coefficients in Two Linear Regressions," Econometrica, vol. 28, no. 3, 1960, pp. 591-605.
} 
Table 4

The following model is proposed: $\operatorname{lnLOGDI}{ }_{t}=\alpha_{1}+\alpha_{2} D_{t}+\beta_{1} t+\mu_{t}$; Regressand is the logarithm of $Y$ and the regressor is "time," which will take values of 1, 2,3, etc. Dummy Takes the value of 0 for older subperiod and 1 for latter subperiod. Subperiods 19732000 and 2000-2008, annual data. Data adjusted for autocorrelation via Newey-West HAC Standard Errors \& Covariance (lag truncation=5). Data source: Bureau of Economic Research.

Dependent Variable: logarithm of Disposable income

(LOGDI)

Method: Least Squares

Sample: 136

Included observations: 36

Newey-West HAC Standard Errors \& Covariance (lag truncation=3)

\begin{tabular}{lrlrr}
\hline \hline \multicolumn{1}{c}{ Variable } & Coefficient & \multicolumn{1}{c}{ Std. Error } & t-Statistic & Prob. \\
\hline \multicolumn{1}{c}{ C } & 7.014048 & 0.073117 & 95.92854 & 0.0000 \\
\multicolumn{1}{c}{ DUM } & -0.211163 & 0.082883 & -2.547738 & $\mathbf{0 . 0 1 5 7}$ \\
\multicolumn{1}{c}{ TIME } & 0.072023 & 0.004164 & 17.29846 & $\mathbf{0 . 0 0 0 0}$ \\
\hline \hline R-squared & 0.987015 & Mean dependent var & 8.293680 \\
Adjusted R-squared & 0.986228 & S.D. dependent var & 0.696489 \\
S.E. of regression & 0.081735 & Akaike info criterion & -2.091010 \\
Sum squared resid & 0.220461 & Schwarz criterion & -1.959050 \\
Log likelihood & 40.63817 & Hannan-Quinn criter. & -2.044952 \\
F-statistic & 1254.216 & Durbin-Watson stat & 0.293114 \\
Prob(F-statistic) & 0.000000 & & \\
\hline \hline
\end{tabular}

Disposable income (DI) has actually been growing more slowly in 2000-2008 period than in 19732000 period. Consequently, bank asset growth has not coincided with surge in disposable income but has coincided with surge in consumer credit. This has led to $2^{\text {nd }}$ round of CC decoupling from DI. It seems that it is stock markets that have been driving consumer wealth in mid 1990s that have affected consumption pattern. After 2000 housing was increasing wealth and drove consumption higher. CC/Wealth is the only variable that remained stationary, i.e. mean reverting, for the period 1973-2008 as shown in Table 5. 
Table 5

Null Hypothesis: CC/Wealth ratio has a unit root

Exogenous: Constant

Lag Length: 9 (Automatic based on SIC, MAXLAG=17)

\begin{tabular}{lrrr}
\hline \hline & \multicolumn{1}{l}{ t-Statistic } & \multirow{2}{*}{ Prob.* } \\
\hline \hline \multicolumn{2}{l}{ Augmented Dickey-Fuller test statistic } & -3.574630 & $\mathbf{0 . 0 0 6 7}$ \\
\hline Test critical values: & 1\% level & -3.445701 & \\
& 5\% level & -2.868202 & \\
& 10\% level & -2.570384 & \\
\hline \hline
\end{tabular}

*MacKinnon (1996) one-sided p-values.

Augmented Dickey-Fuller Test Equation

Method: Least Squares

Included observations: 420 after adjustments

These results are consistent with findings of Barrell and Davis 2007 who found that removal of liquidity constraints during liberalization may reduce the response of consumption to real personal income, and what is most important, may boost wealth effect correspondingly ${ }^{6}$. By employing various econometric technique, they test the relationship between consumption, income and aggregate real net wealth in the long term that is augmented by a split between changes in tangible wealth and financial wealth in the short term. What they find is that when financial liberalization takes place, the coefficient on human wealth (i.e. income) may be reduced, as scope for borrowing means consumption is less closely tied to current income. Furthermore, the weights on financial and non financial nonhuman wealth could change with liberalization. When households are constrained in their borrowing, direct liquidity of the components of wealth will be crucial for their effect on consumption. A lower weight would be anticipated for less liquid assets and especially for tangible wealth. When there are no credit constraints, as in a liberalized financial system, consumers can borrow to cover shortfalls in income and the ability to consume out of wealth, and in particular illiquid wealth. Higher wealth effects, especially in the short run dynamics of adjustment, are thus likely both for illiquid financial assets (equities, bonds, pension assets) and non financial tangible wealth. Byrne and Davis (2003) highlighted that illiquid as well as liquid financial wealth is likely to become important in determining consumption in the G-7, and indeed showed in rolling regressions that there has been a rise in the long run impact of

\footnotetext{
${ }^{6}$ Similar studies have been performed by Davis and Palumbo's (2001) study of the US consumption function, which attempted to determine whether changes in wealth as well as income affect the growth rate of consumer spending. Ludvigson and Steindel (1999) also examined wealth effects in a quarterly loglinear long-run US consumption relationship and found a common trend and a statistically significant wealth and income effect (Barrell and Davis 2007)
} 
illiquid financial wealth on consumption. Modelling the G-5, Barrell and Davis (2004) highlighted that absence of credit constraints also affects non-financial tangible wealth. The incidence of liquidity constraints was considered to be shown inter alia by the relative size of income and wealth terms in the consumption function, which was a crucial difference between their estimates over 1980-2001 for less liberalised countries such as Germany and Japan vis a vis France, the UK and US. Meanwhile, tangible wealth was generally significant in both the short and long run.

Jaewoo, Rabanal and Sandri (2010) found that wealth effect was a primary factor behind the rapid decline in the U.S. saving rate (raise in consumption rate) in the late 1990s. They found that highwealth groups which benefited most from raising wealth decreased substantially their saving rate, while low-wealth groups changed little or even increased their saving rate.

\section{Emerging market perspective}

The Chinese government has called for rebalancing the economy towards greater reliance on consumption as the driver of growth, away from investment and external trade as has been in recent years ${ }^{7}$. Underlying this, is the striking trend of continuing decline in the share of household consumption in GNP, which has fallen to below 40 percent in 2005, despite the remarkable pace of sustained high economic growth. In explaining this declining share of consumption, studies have largely focused on the household savings behavior, arguing that this trend reflects the high and rising savings by Chinese households (Blanchard and Giavazzi (2005), Kujis (2005), Modigliani and Cao (2004), Prasad and Rajan (2005)), due to a range of factors such as the rise in average household income, the increase in the proportion of working age population, and an increase in precautionary savings with the rise in the uncertainties during reforms (especially that of stateowned enterprises) and inadequate public provision of pensions, healthcare, and education. While there is little doubt that these factors could be important in explaining the rise in the household saving rate, it is less convincing that these are the main reasons for the decline in the consumption share. In fact, data suggests that the increase in saving alone explains only a small fraction of the decline in the consumption share. The rise in household saving rate of 5 percentage points since the early 1990s can only explain 1 percentage of the 9 percentage points decline in the share of consumption that has occurred since then. During the same time the share of household income in

\footnotetext{
7 See for example, Zhou Xiaochuan's (Governor of the People's Bank of China) foreword in Jahangir Aziz et. al edited, "China and India: Learning from Each Other," IMF, 2006.
} 
GNP declined by 8 percentage points. The decline in household income's share occurred across all major sub-categories, but particularly in wages, which, unsurprisingly, is the largest component of income. The shares of investment income and government transfers also fell. Given that the decline in wage income was the largest contributory factor, it may be tempting to seek an answer in China's labor market. With 100-150 million workers either unemployed or underemployed, it is perhaps easy to argue that this slack in the labor market has prevented wages from rising as fast as productivity, leading to the continued decline in the share of wage income. If one adds to that some degree of monopolistic power in the hands of the employers and ineffective worker protection, then it is even easier to see why workers have not benefited from the huge productivity gains the economy has enjoyed.

Aziz and Cui (2007) has shown that China's underdeveloped financial sector and persistent and rising difficulty for average firms to obtain financing has played a major role in explaining the $c^{-}$ movements in employment, household income, and consumption over the last two decades. Specifically, Chinese firms rely on bank financing for working capital to pay wages and other current expenditure, where they are credit constrained. These borrowing constraints act like taxes on labor input that discourage the use of labor and create a wedge between the market wage rate and the marginal product of labor. Because of this wedge, the labor share in national income is less than its technologically determined share and the more difficult it is for firms to borrow, the larger is this wedge and lower is labor share. The paper showed that since the mid-1990s, pressures to reform forced Chinese banks to become more conservative in their lending operations to avoid creating new non-performing loans, which tightened borrowing constraints of firms, leading to a decline in the wage share. The declining share of wage income, however, would not necessarily have led to such a steep fall in household income share, if rising profits were distributed to households. This did not happen in China for several reasons. First, despite some listing in domestic stock markets, ownership of Chinese firms is not widely held, either directly or indirectly (through institutional investors and pension funds), by households. Second, even for firms that are listed, weak corporate governance and minority shareholding rights have allowed firms to accumulate profit instead of distributing dividends. A string of scandals in the past few years associated with poor supervision of brokerage firms led to a protracted period of depressed equity prices and limited transactions such that households who owned shares did not benefit from underlying capital gains. Third, the government still retains considerable ownership of the corporate sector. In most countries, this has been a conduit of indirectly transferring corporate 
profit to households. State-owned enterprises (SOEs) pay dividends to the government, which uses the funds to provide goods such as education and health that are essentially private goods, and welfare payments. In China, SOEs do not pay dividends to the government, such that this conduit of profit transfer has been closed. Lastly, bank deposits are the main vehicle of savings of Chinese households. However, the interest rate on household deposits has been capped by the government. Consequently, the share of interest earnings has declined over the years. China's banks have, of course, enjoyed higher interest rate margins. However, with much of the banking sector, burdened with high non-performing loans, under-capitalized, and under-provisioned until only last year, the higher interest margin has, for all practical purposes, ended up as being "transfers" from households to corporations. For these reasons and unlike in many other countries, the rise in corporate profits did not translate into higher household income in China. The comparison with international experience is striking. During the past decade, less than 8 percent of households' disposable income came from investments (including profit, interest rate, etc). This is one of the lowest in the world.

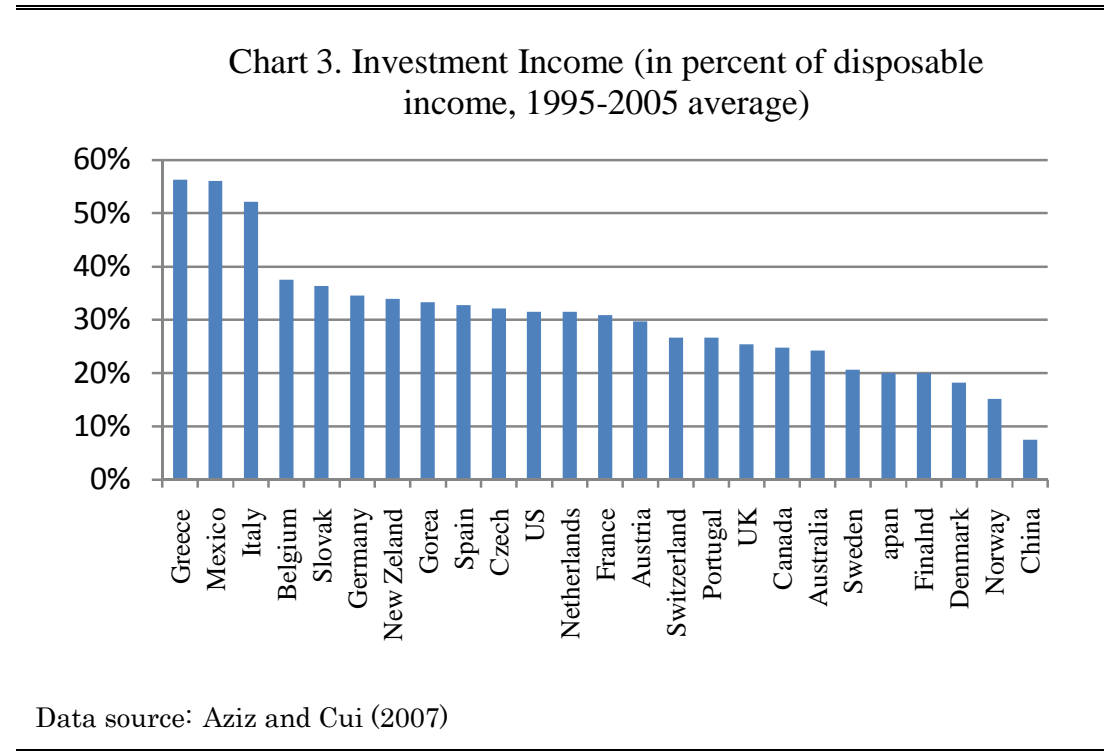

The nexus between financial sector development and growth is a long standing branch of economics literature. However, much of this literature, especially on the empirical front, has focused on the role played by financial intermediaries in mobilizing savings and some on their role in allocating savings. On the first role in China, earlier studies found that the banking sector did not contribute that much to growth through resource mobilization and allocation (see e.g., Aziz and 
Duenwald (2002)). Instead, bank financing was largely concentrated in the more sluggish stateowned enterprises, which could have aided growth indirectly by helping to maintain social stability in the economy. The low share of investment income in China brings into sharp focus the poor performance of the financial sector to distribute profit income from firms to households, both in the form of dividends and interest.

China's stock market is relatively small despite the rise of private firms and the dilution of public ownership through listings in the stock market and through sales to foreign investors.

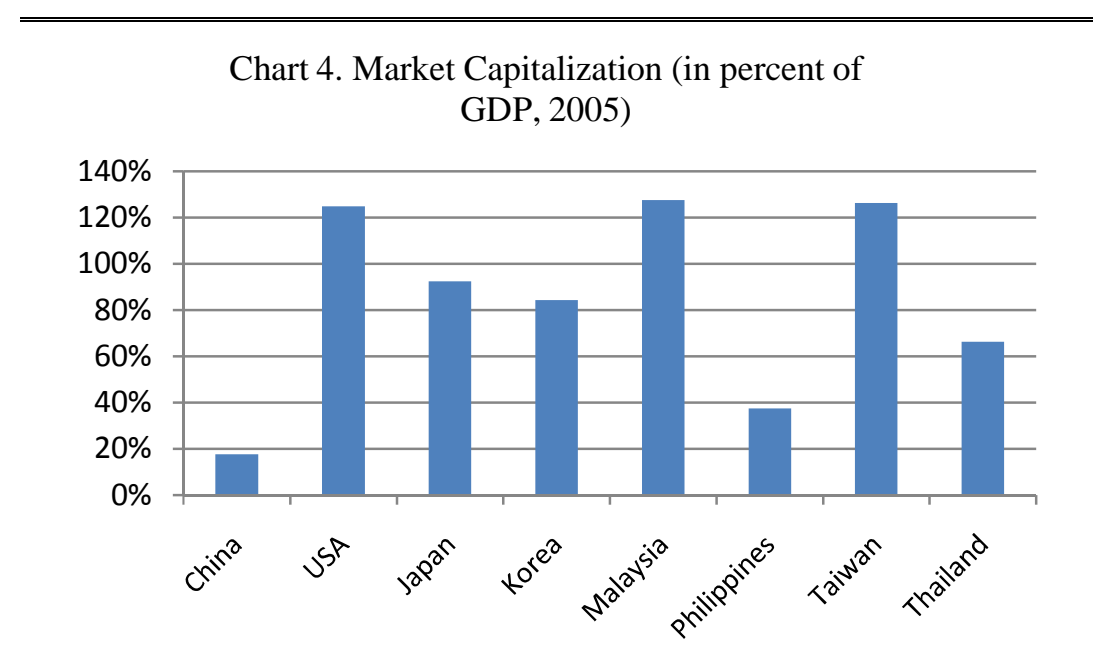

Data source: Aziz and Cui (2007)

Until recently, about two thirds of the shares of the listed companies in China's stock market were nontradable. The uncertainties about how the issue may be resolved have resulted in depressed stock prices and low market participation in recent years. The development of institutional investors (such as mutual funds, insurance, and pension funds) has been sluggish. In China, such investment funds were established in 1998. By the end of 2002, there were only 61 closed and open-ended investment funds, holding investment assets of less than 10 percent of tradable market capitalization, compared with 50 percent in the U.S. 


\section{Housing wealth in China}

During the late 1980s and the 1990s, households in most Chinese cities were offered the chance to purchase the apartments that they rented from the state, thereby untying access to housing from working in the state sector and giving urban residents a chance to become private homeowners. These reforms were enacted in at least 50 cities, potentially affecting more than 90 million people. Iyer, Meng and Qian (2009) find that the privatization reform caused private ownership of housing to increase from zero to approximately $50 \%$ of urban households. The untying of housing from state employment is probably the main driving force for this result, rather than the acquisition of private property rights. While it is not possible to test this directly, it is possible to individually test some of the implications of the different channels of private property rights like the importance of the credit channel for example. Though households in China at the time did not have access to credit from formal financial institutions for small businesses, private property can potentially be used as collateral for informal loans.

Iyer, Meng and Qian (2009) present evidence that the housing privatization reform did not increase households ability to obtain credit, in keeping with the institutional setting in China. Households are not more likely to have either a housing loan or a non-housing loan following the enactment of housing privatization reforms. Iyer, Meng and Qian (2009) also find that the estimated coefficients for the effect of the reform on total household consumption and expenditure on housing improvements are small, negative and statistically insignificant. All of this suggests that the reform did not significantly increase household wealth ${ }^{8}$.

\section{Conclusion}

Consumer credit has decoupled from disposable income in mid 1990s when equity market growth rates have changed. Consumer credit has also decoupled from disposable income in 2000s when Glass-Steagall act has been repealed, which allowed banks to be involved in investment activity in sophisticated financial instruments which in turn made previously illiquid assets (real estate) liquid, therefore raising demand on such instrument and therefore their price. Increasing consumption in developed markets caused by reliance of consumers on equity markets as well as

\footnotetext{
${ }^{8}$ Any potential wealth effects are likely to be unimportant in the case of the privatization reforms, because households could not sell the newly acquired housing until the cities enacted the trading reforms.
} 
ability to withdraw equity from appreciating real estate has been at the core of consumer spending expansion. Consumer Credit has been increasing with consumer wealth, leaving CC/W ration stationary. Chinese have neither developed stock market to benefit from raising corporate profits via dividends nor bond market - they are limited to deposits which rates are depressed. Neither there is an ability to withdraw equity from housing as well as privatization did not result in increased wealth by the households. We conclude that disposable income by itself is not sufficient to fund increased consumption - neither there are any conditions for increased disposable income in China. In summary, consumer as the engine of economic growth is simply non-existent in China to the degree that it exists in US and this phenomenon has to do with economic structure (financial architecture) of the economy. Credit tightening is closely associated with both rising uncertainty and declining wealth. And a large uncertainty appreciably reduces consumption not only via a lower wealth and tighter credit, but also directly via precautionary savings and postponed consumption. Deleveraging cycle in the banking sector has just begun. It is unclear to what degree will this have an effect on consumer spending or to the wealth of the consumer balance sheet. However it seems that claim of change in paradigm and superiority of new emerging market consumer is simply not supported by any plausible argument, empirical research or statistical analysis.

Exposure to relative disadvantage of EM (China) consumer can be structured via shorting The Global X China Consumer ETF and taking long positions in Consumer Discretionary SPDR ETF as well as Consumer Staples SPDR ETF.

Chart 5.US Consumer//China Consumer Ratio.

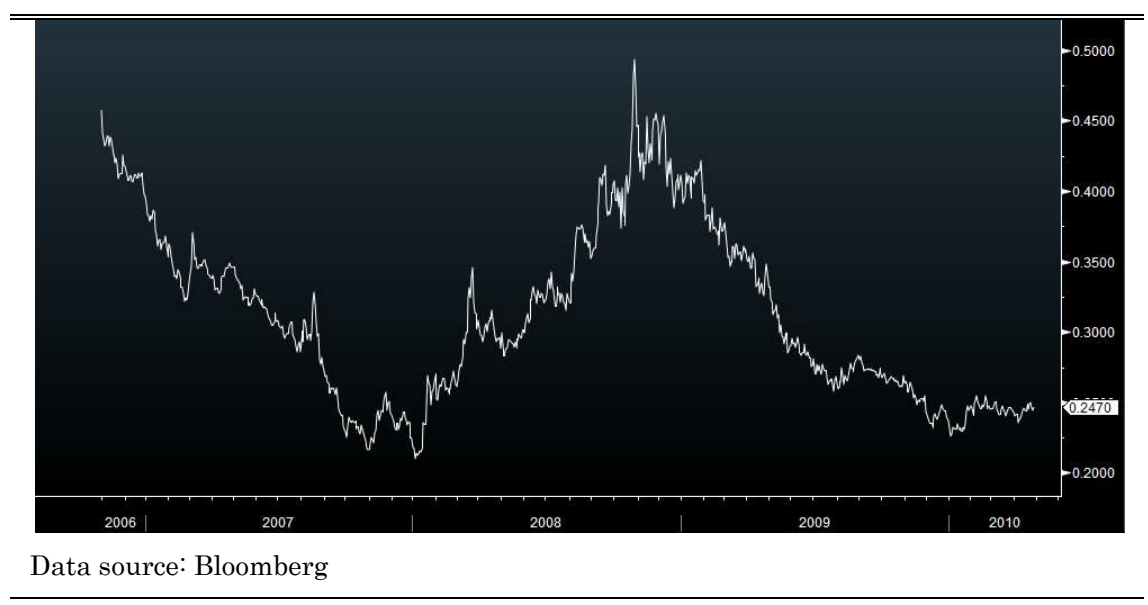




\section{References:}

Ashoka Mody and Franziska Ohnsorge, After the Crisis: Lower Consumption Growth but Narrower Global Imbalances? IMF Working Paper, 2010

Aziz, Jahangir, and Christoph Duenwald, 2002, "The Growth-Financial Nexus," China:

Competing in the Global Economy, edited by Wanda Tseng and Markus Rodlauer.

Blanchard, Oliver, and Francesco Giavazzi, 2005, "Rebalancing Growth in China: A Three-

Handed Approach," CEPR Discussion Paper.

Byrne, J.P.and Davis, E.P. (2003). "Disaggregate Wealth and Aggregate Consumption: An Investigation of Empirical Relationships for the G7", Oxford Bulletin of Economics and Statistics, $65,197-220$

David Laibson, Johanna Mollerstrom; Capital Flows, Consumption Booms and Asset Bubbles: A Behavioural Alternative to the Savings Glut Hypothesis. NBER Working Paper No. 15759* 2010

Emanuele Baldacci, Giovanni Callegari, David Coady, Ding Ding, Manmohan Kumar, Pietro Tommasino, and Jaejoon Woo1 Public Expenditures on Social Programs and Household Consumption in China, IMF Working Paper, 2010

Jaewoo Lee, Pau Rabanal, and Damiano Sandri; INTERNATIONAL MONETARY FUND

Research Department; U.S. Consumption after the 2008 Crisis, 2010

Jahangir Aziz and Li Cui, Explaining China's Low Consumption: The Neglected Role of Household Income IMF Working Paper 2007

Kuijs, Louis, 2005, "Investment and Saving in China," Policy Research Working Paper No. 3633 (Washington: World Bank).

Lakshmi Iyery Xin Mengz Nancy Qian; Unbundling Property Rights: Urban Housing Privatization and Labor Mobility in China, 2009

Ludvigson, S. and Steindel, C. (1999). "How Important is the Stock Market Effect on Consumption?" Economic Policy Review, Federal Reserve Bank of New York, July.

Modigliani, Franco and Shi Cao, 2004, "The Chinese Saving Puzzle and the Life-Cycle Hypothesis," Journal of Economic Literature, pages 145-170.

Marcos Chamon, Eswar Prasad; WHY ARE SAVING RATES OF URBAN HOUSEHOLDS IN CHINA RISING? NBER WORKING PAPER SERIES; Cambridge, 2008

Prasad, Eswar, and Raghuram Rajan, 2006, "Modernizing China's Growth Paradigm," IMF Policy Discussion Paper No. 06/3(Washington: International Monetary Fund). 
Ray Barrell and E Philip Davis; FINANCIAL LIBERALISATION, CONSUMPTION AND WEALTH EFFECTS IN 7 OECD COUNTRIES, NIESR Discussion paper no. 247; NIESR and Brunel University London, 2007

Steve Barnett and Ray Brooks1 China: Does Government Health and Education Spending Boost Consumption? IMF Working Paper, 2010 